\title{
Integrated Optical, Micro-Raman, and Compositional Analysis of Rock Samples from Former Talc Mines in the Gouverneur Mining District, New York
}

\author{
Brittani D. McNamee \\ Environmental Studies, University of North Carolina, Asheville
}

Aaron J. Celestian

Mineral Sciences, Natural History Museum of Los Angeles 


\section{Gouverneur Talc District}

- Talc mined since 1948 primarily for fillers in ceramics, paper, and paint.

- Metamorphosed dolomite marbles and quartzites with Ca-Mg silicates.

- Purported asbestos particles found in children's crayons in 2000. 


\section{Project Goals}

- Characterize minerals of interest:

- tremolite $\quad \mathrm{Ca}_{2} \mathrm{Mg}_{5} \mathrm{Si}_{8} \mathrm{O}_{22}(\mathrm{OH})_{2} \quad \mathrm{SiO}_{2} / \mathrm{MgO}=2.4$

- anthophyllite $\mathrm{Mg}_{7} \mathrm{Si}_{8} \mathrm{O}_{22}(\mathrm{OH})_{2} \quad \mathrm{SiO}_{2} / \mathrm{MgO}=1.7$

- talc $\quad \mathrm{Mg}_{3} \mathrm{Si}_{4} \mathrm{O}_{10}(\mathrm{OH})_{2} \quad \mathrm{SiO}_{2} / \mathrm{MgO}=2.0$

- Compare electron microprobe analyses with Micro-Raman of the same polished thin section and both methods have been used with similar mineral samples. 


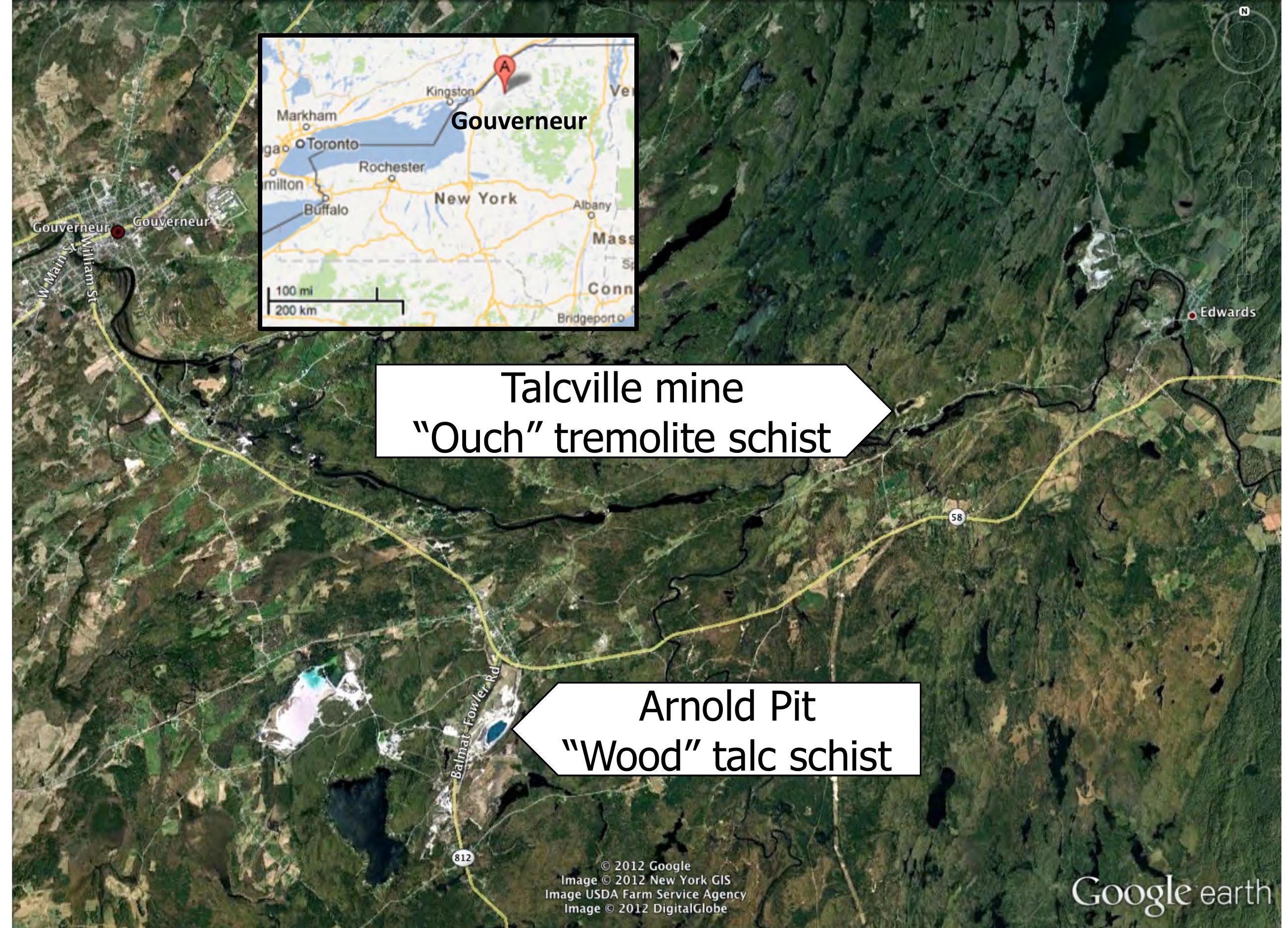




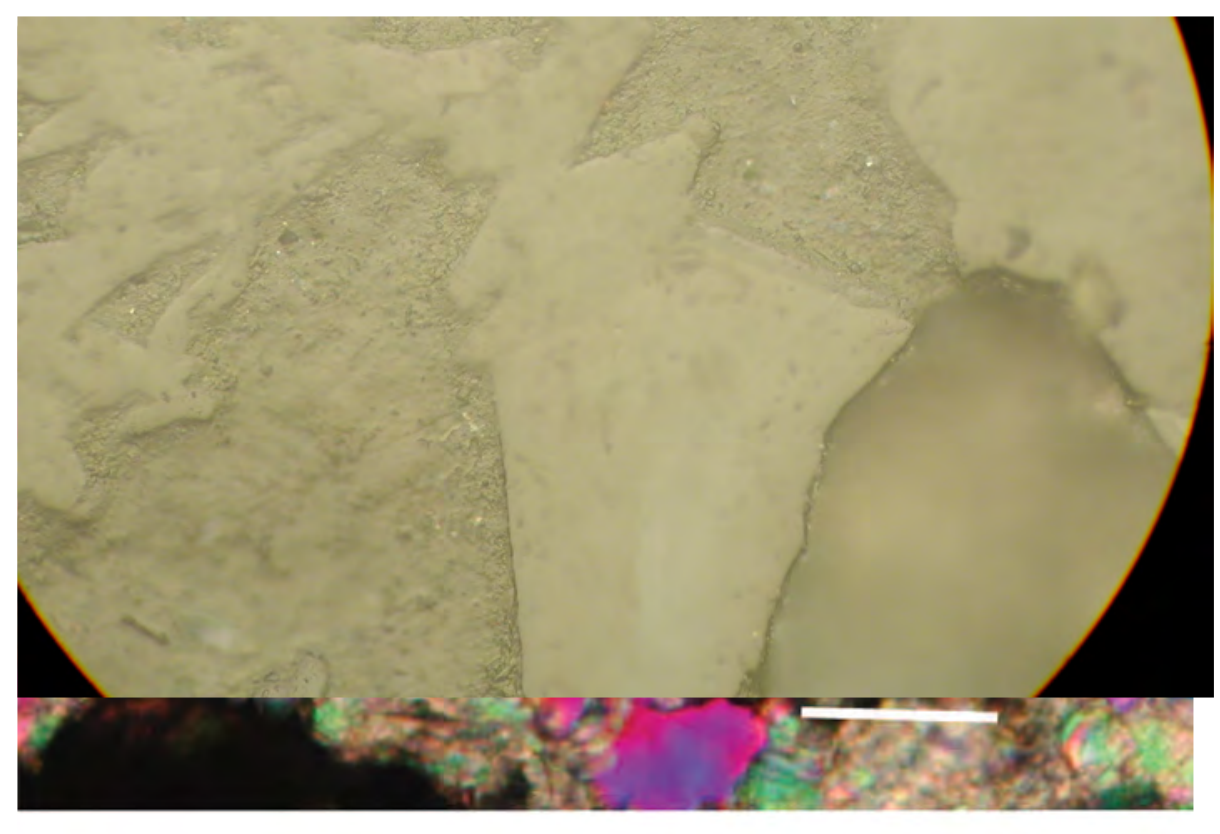

"Wood" C1

fine-grained talc

$\mathrm{SiO}_{2} / \mathrm{MgO} 1.96$

$\mathrm{MnO} 0.02 ; \mathrm{CaO} 0.12$
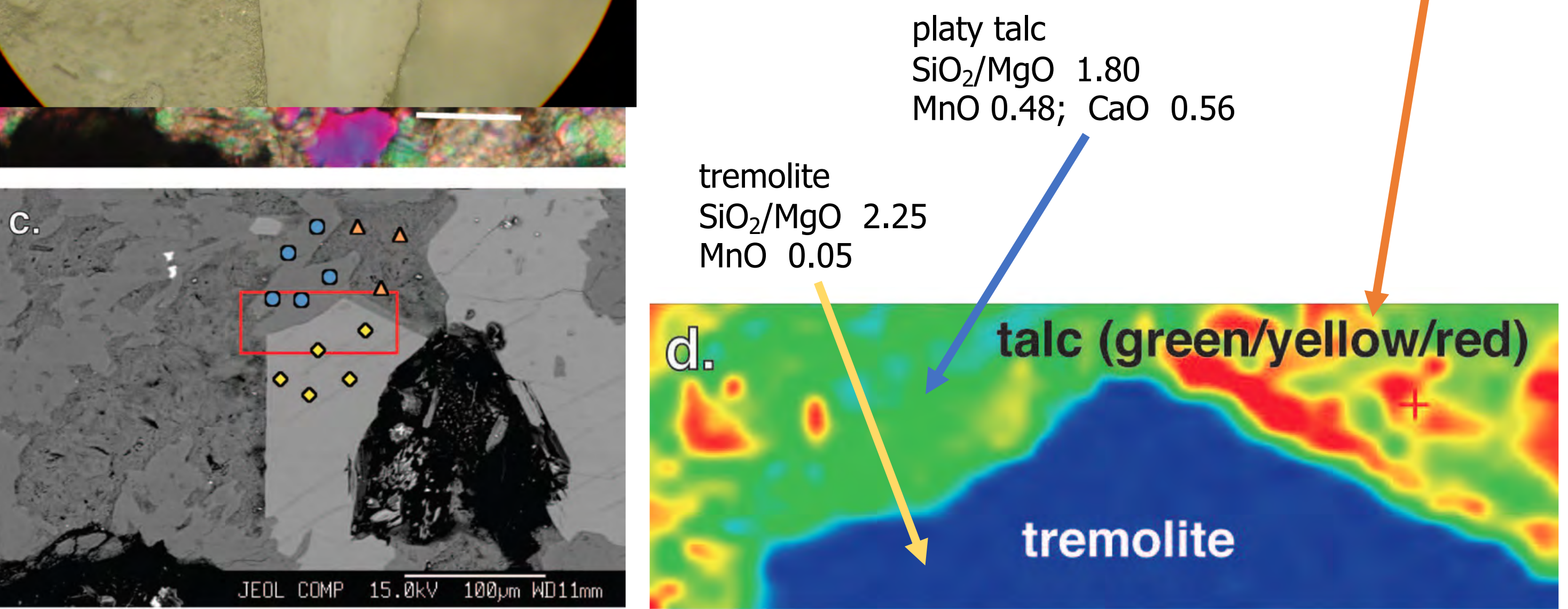

\section{tremolite}




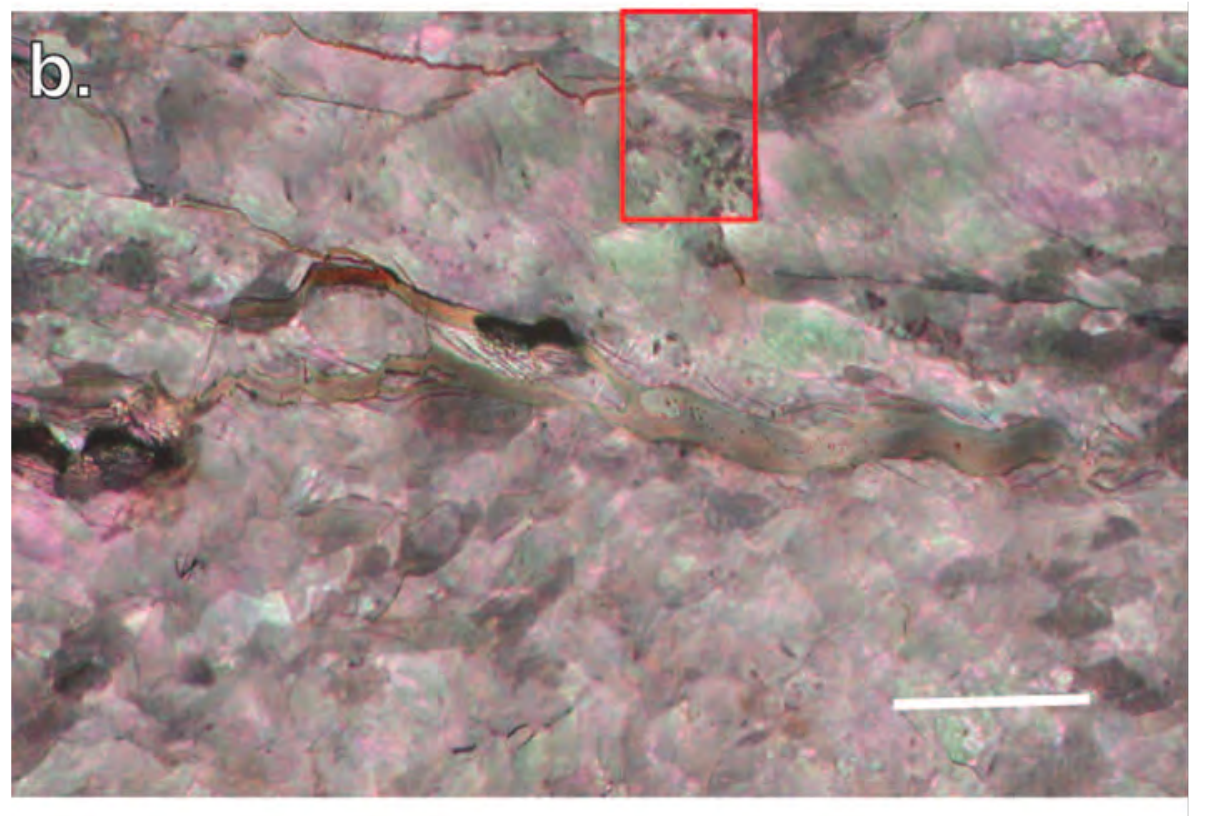

\section{"Wood" C2}
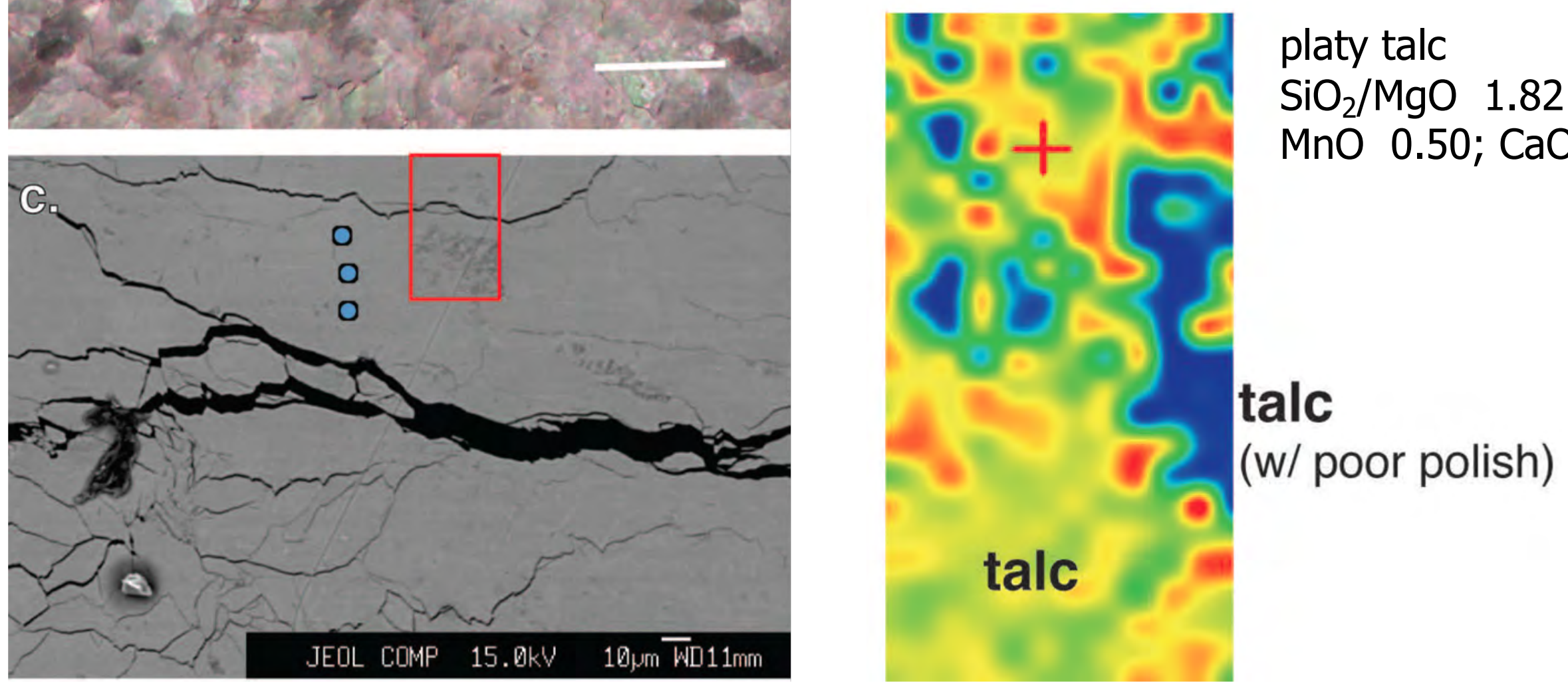


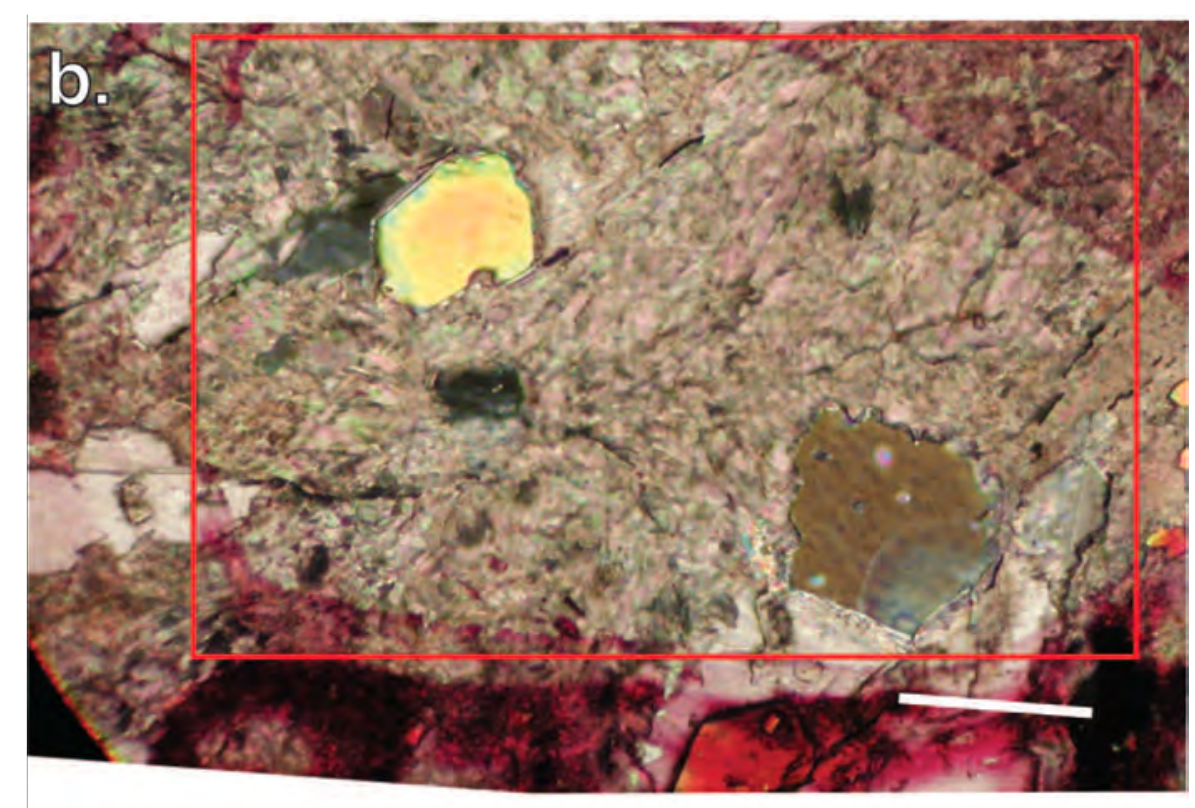

\section{"Wood" C3}

platy talc

$\mathrm{SiO}_{2} / \mathrm{MgO} 1.82$

$\mathrm{MnO} \quad$ 0.43; $\mathrm{CaO} 0.39$
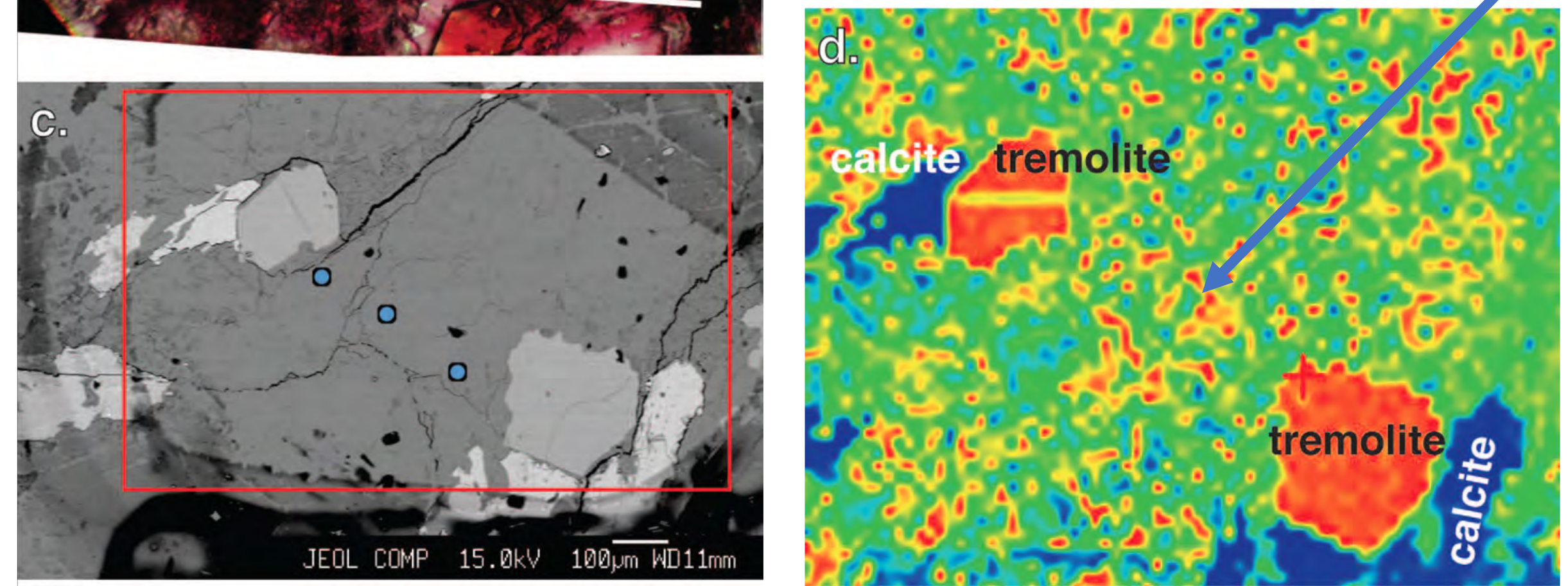


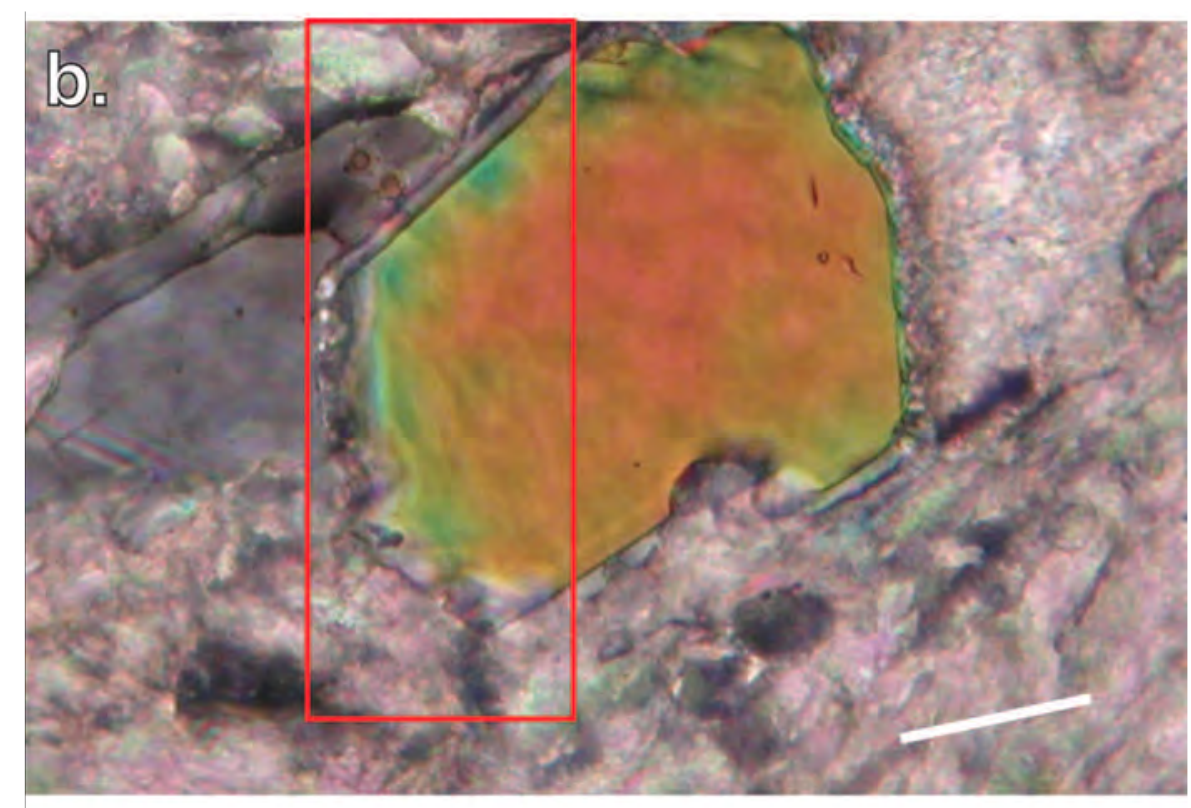

\section{"Wood" C3 close up on the tremolite}
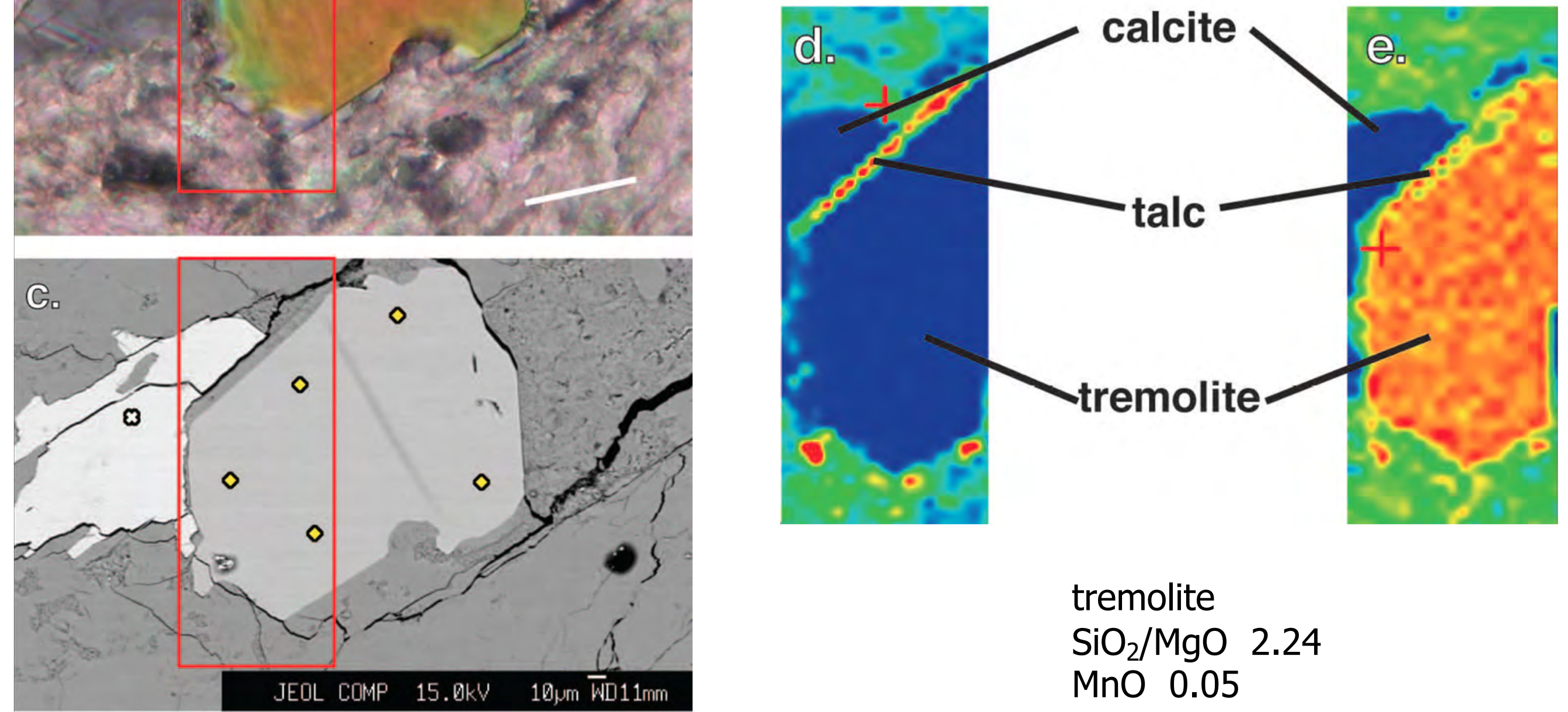

tremolite

$\mathrm{SiO}_{2} / \mathrm{MgO} 2.24$

$\mathrm{MnO} 0.05$ 


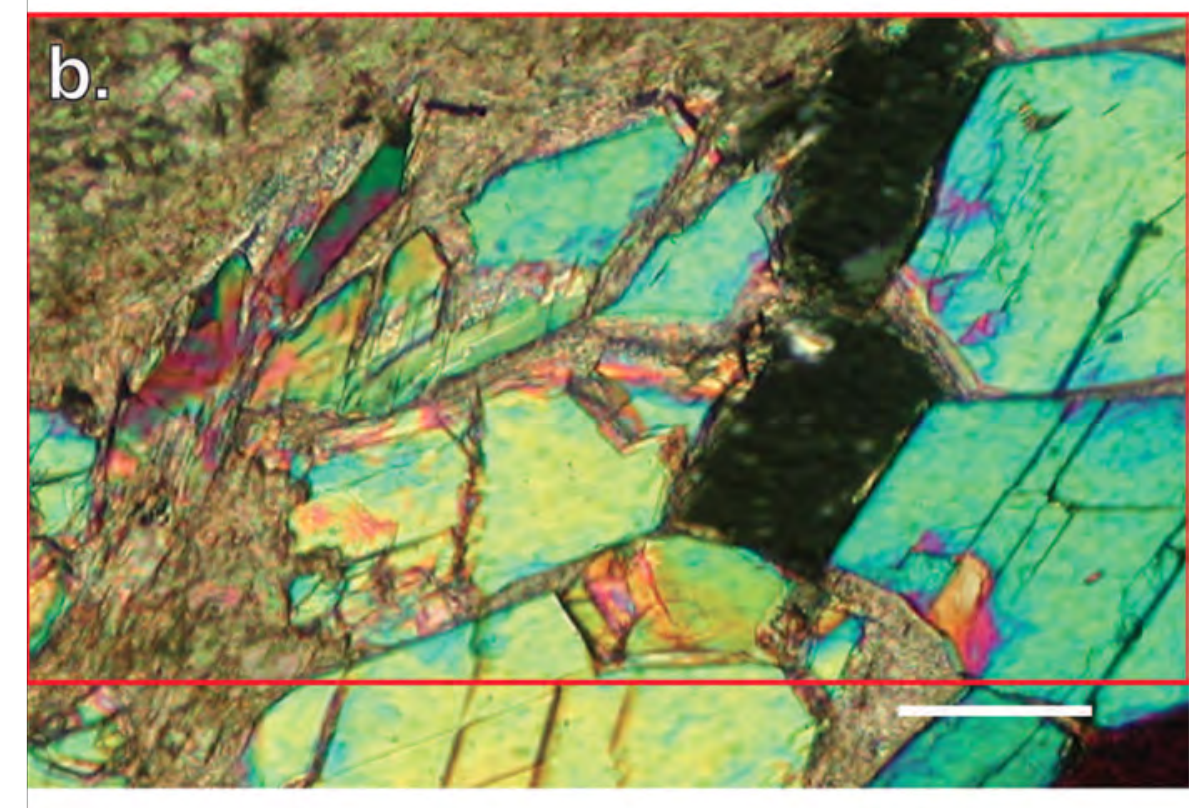

\section{"Wood" C4}

fine-grained talc

$\mathrm{SiO}_{2} / \mathrm{MgO} 1.88$

tremolite

$\mathrm{SiO}_{2} / \mathrm{MgO} 2.22$

$\mathrm{MnO} 0.02 ; \mathrm{CaO} 0.19$

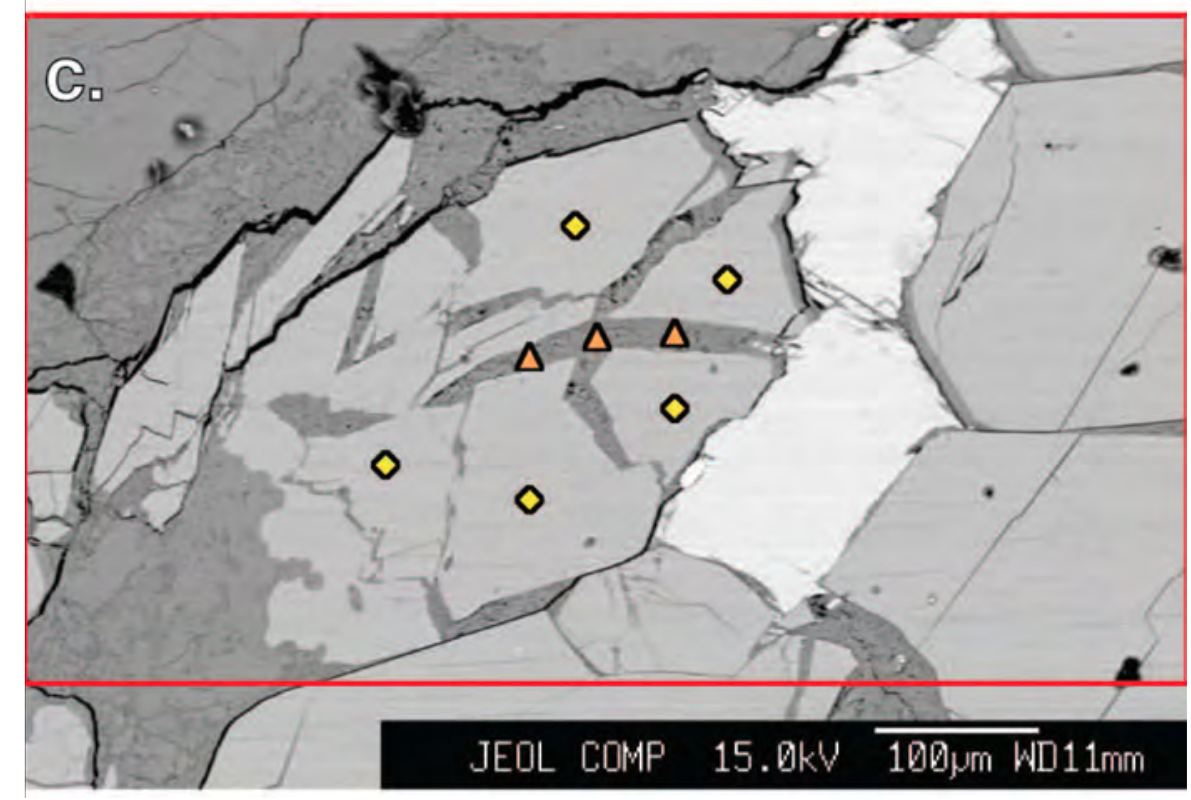

$\mathrm{MnO} 0.06$
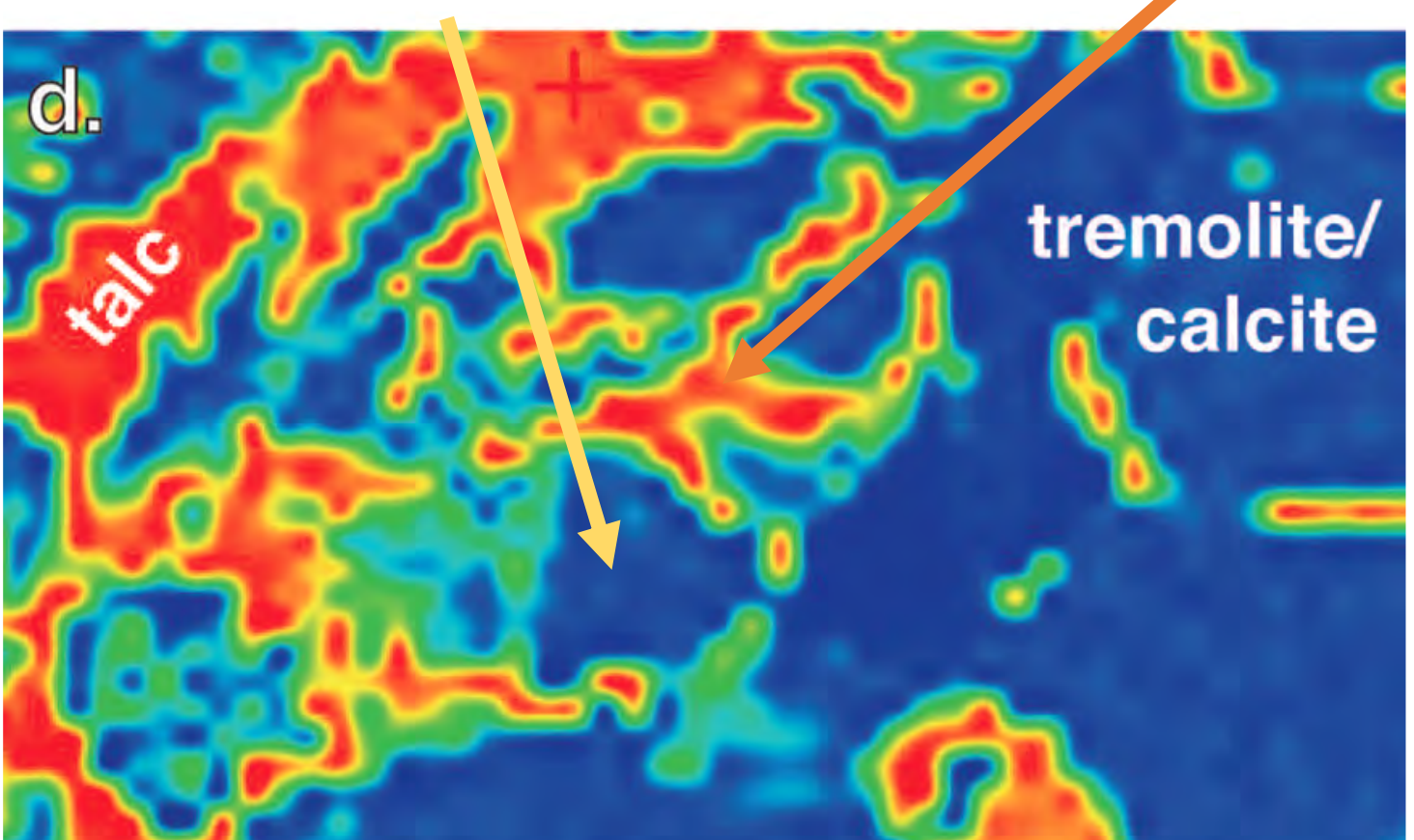


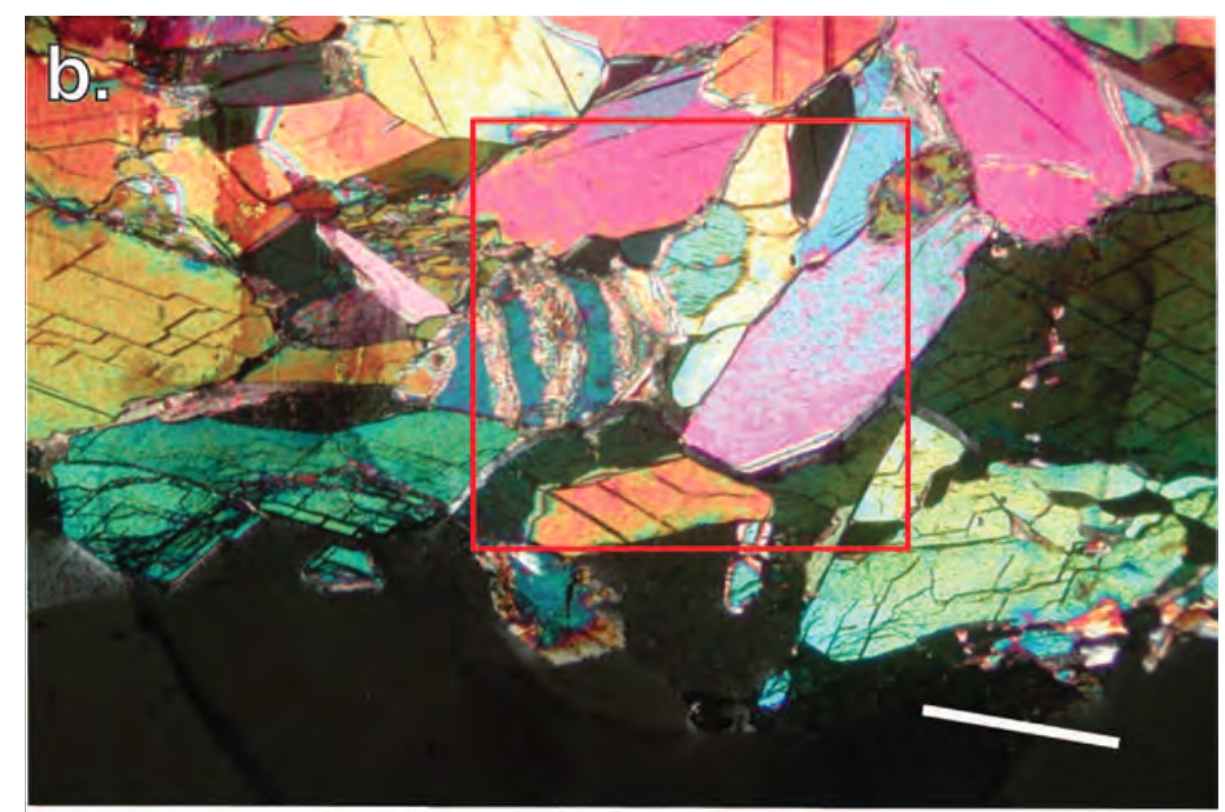

\section{"Ouch" C3}

anthophyllite

tremolite

$\mathrm{SiO}_{2} / \mathrm{MgO} 2.25$

$\mathrm{MnO} 0.53$
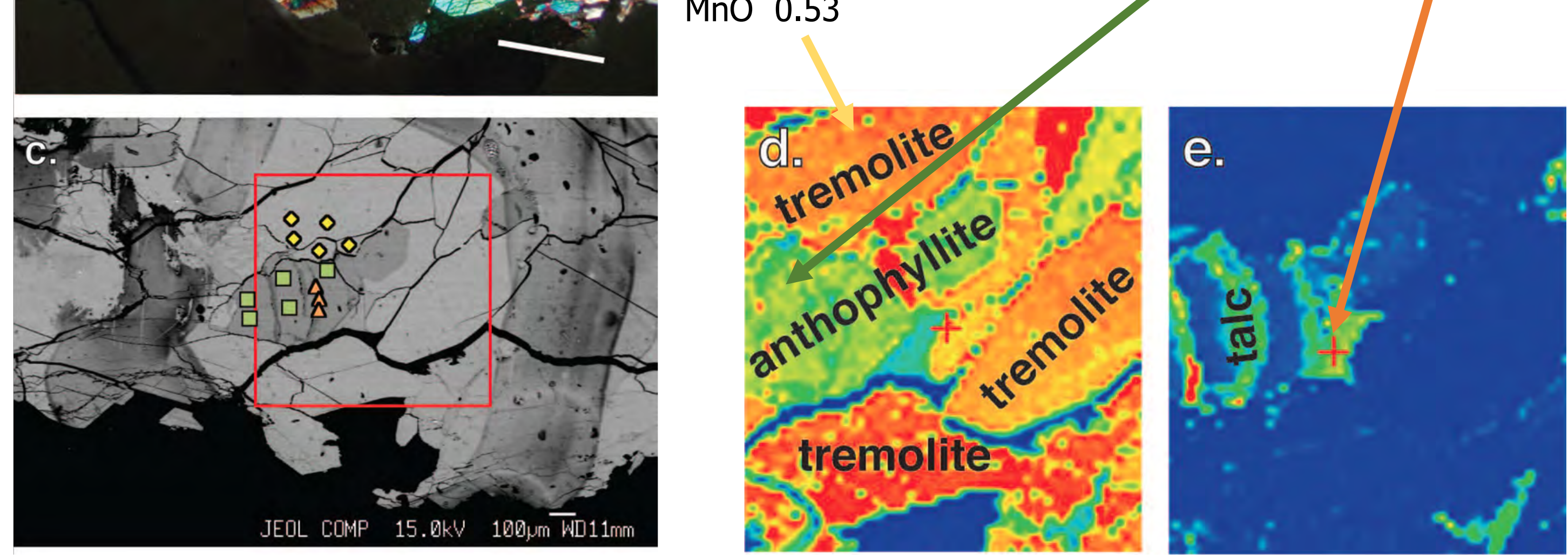

fine-grained talc

$\mathrm{SiO}_{2} / \mathrm{MgO} 2.25$

$\mathrm{MnO} 0.40 ; \mathrm{CaO} 0.11$
$\mathrm{SiO}_{2} / \mathrm{MgO} 1.73$

$\mathrm{MnO}$ 1.50; $\mathrm{CaO} 0.45$ 


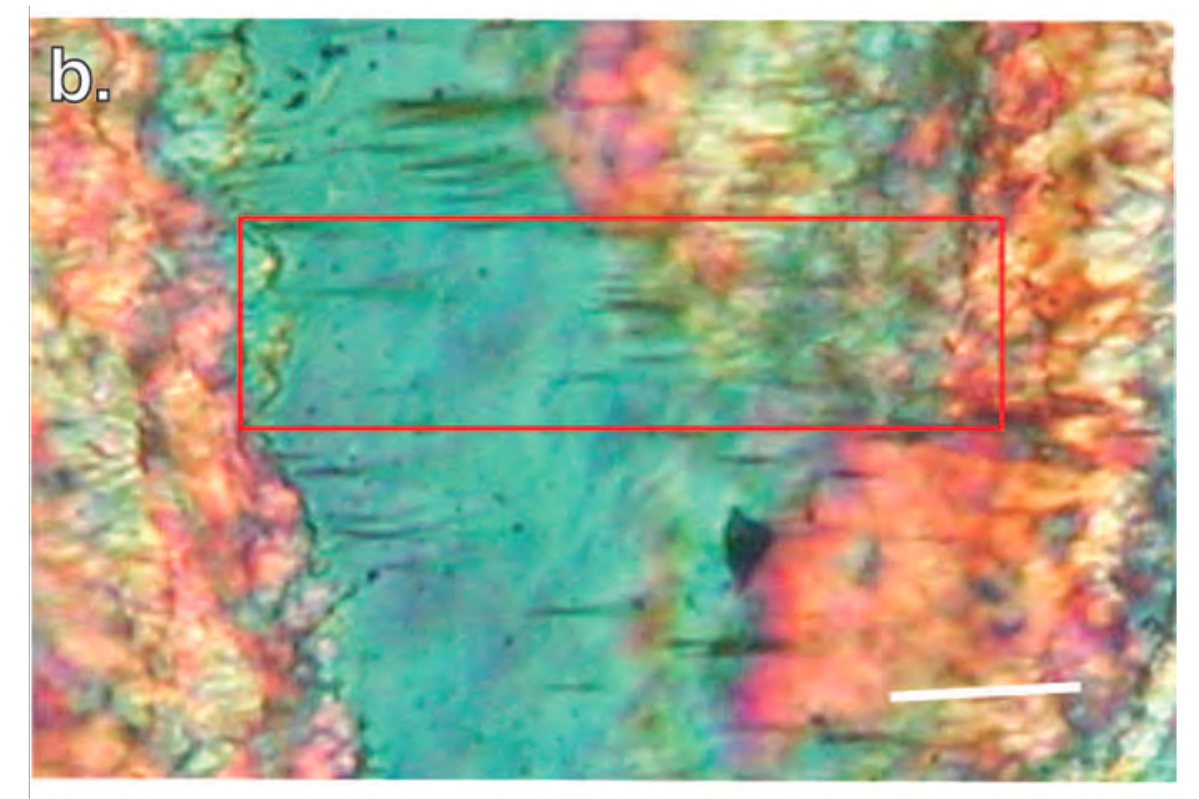

\section{"Ouch" C3 anth fracture}
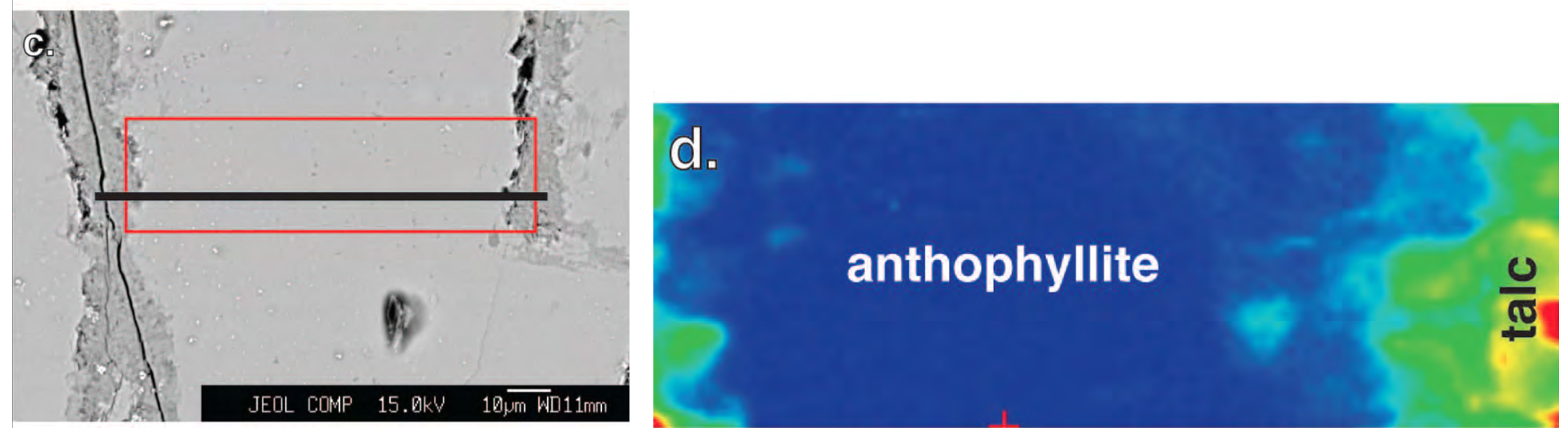


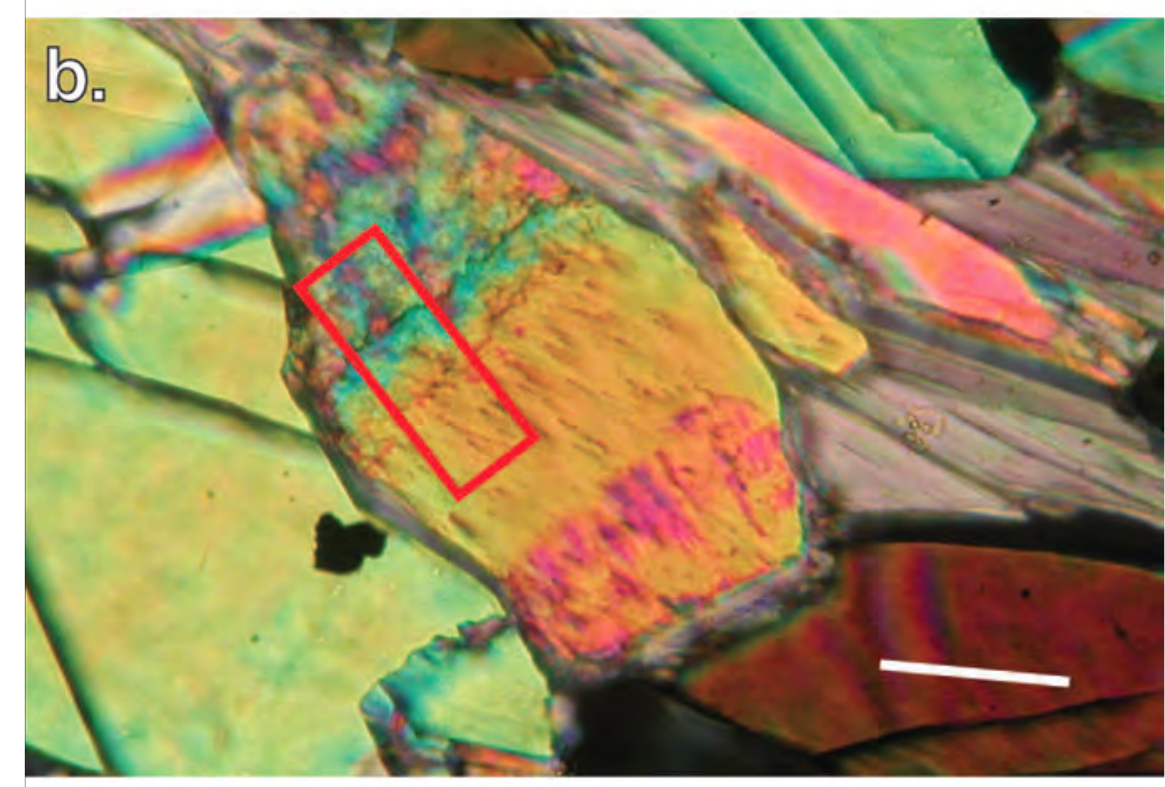

"Ouch" outside C2
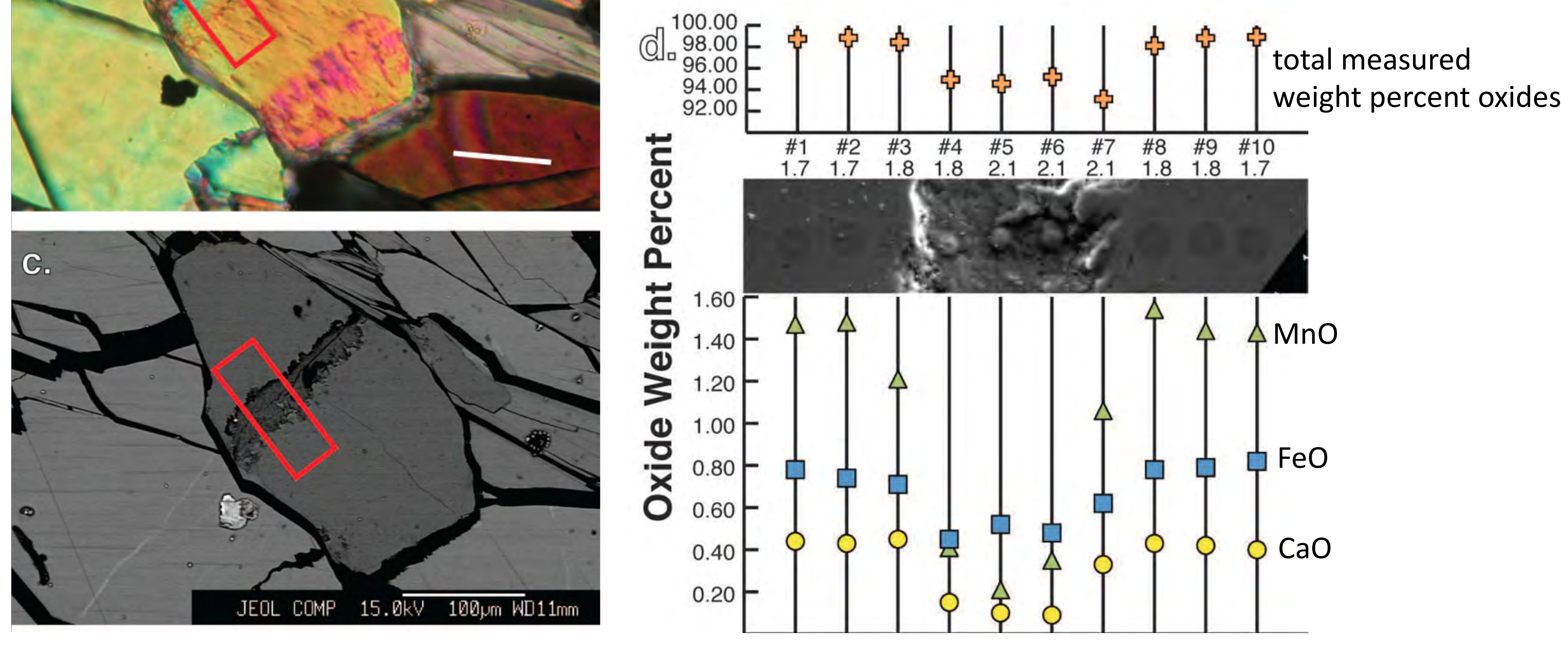


\section{"Ouch" tlc fracture in ath}

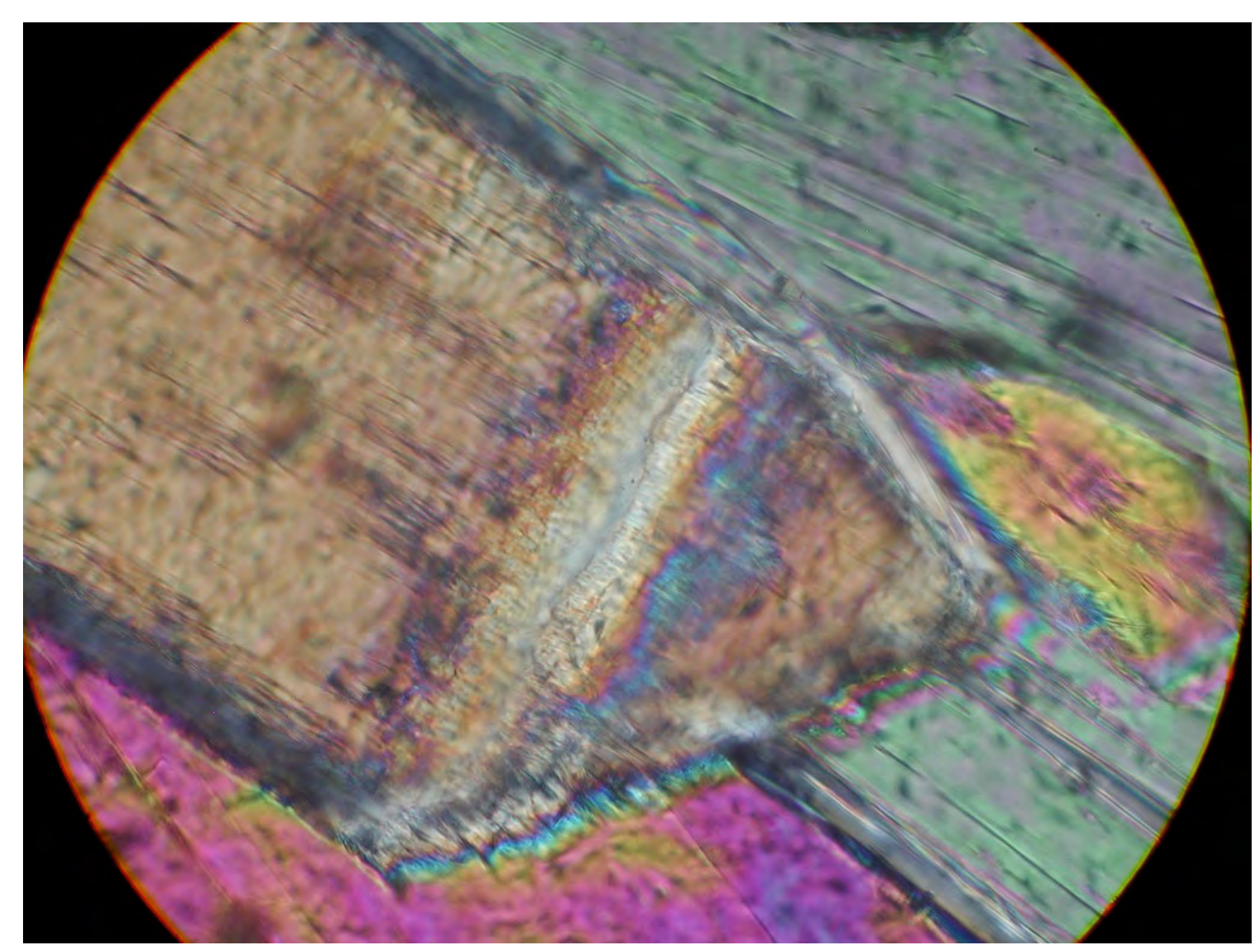




\section{Conclusions: Mineral Characterizations}

- Asbestiform talc forms from acicular anthophyllite. No other asbestiform minerals found.

- Subtle differences in trace elements found in different talc morphologies suggests multiple formations of talc.

- Interactions between talc and anthophyllite occur at such fine scales, both phases could be included in WDS analyses. 


\section{Conclusions: Micro-Raman}

- Allows for comparison of microprobe analyses and Raman spectroscopy of the sample polished thin section.

- Varying intensities of Raman peaks may be due to multiple orientations, especially with fine-grained talc.

- No matter the orientation, the peaks in the Raman spectra collected for talc grains still plotted in the same position, just with varying intensities. 
the

Thank you! Questions? 